\title{
MicroRNA-mediated regulation of flower development in grasses
}

\author{
Aleksandra Smoczynska ${ }^{\bowtie}$ and Zofia Szweykowska-Kulinska ${ }^{\bowtie}$ \\ Department of Gene Expression, Institute of Molecular Biology and Biotechnology, Faculty of Biology, Adam Mickiewicz University in Poznan, \\ Poznań, Poland
}

\begin{abstract}
Flower structure in grasses is very unique. There are no petals or sepals like in eudicots but instead flowers develop bract-like structures - palea and lemma. Reproductive organs are enclosed by round lodicule that not only protects reproductive organs but also plays an important role during flower opening. The first genetic model for floral organ development was proposed 25 years ago and it was based on the research on model eudicots. Since then, studies have been carried out to answer the question whether this model could be applicable in the case of monocots. Genes from all classes found in eudicots have been also identified in genomes of such monocots like rice, maize or barley. What's more, it seems that miRNA-mediated regulation of floral organ genes that was observed in the case of Arabidopsis thaliana also takes place in monocots. MiRNA172, miRNA159, miRNA171 and miRNA396 regulate expression of floral organ identity genes in barley, rice and maize, affecting various features of the flower structure, ranging from formation of lemma and palea to the development of reproductive organs. A model of floral development in grasses and its genetic regulation is not yet fully characterized. Further studies on both, the model eudicots and grasses, are needed to unravel this topic. This review provides general overview of genetic model of flower organ identity specification in monocots and it's miRNA-mediated regulation.
\end{abstract}

Key words: miRNA, grasses, flower development, $A B C D E$ model Received: 06 June, 2016; revised: 25 June, 2016; accepted: 19 July, 2016; available on-line: 04 November, 2016

\section{FLOWER STRUCTURE IN GRASSES}

The spikelet is the basic unit of the grass inflorescence. It is formed directly on the main axis of the inflorescence or on the branches. The pattern of spikelet formation differs depending on the species. The flower in grasses is located inside the spikelet. The grass flower is composed of two bract-like structures, lemma and palea forming most of the outer whorl. The second whorl is occupied by rounded organ-lodicule which covers stamen and carpel, not only protecting these reproductive structures but also ensuring access to them by swelling during flower opening (Fig. 1). The number of flowers formed in a spikelet is variable depending on the species (Clifford 1987, Bommert et al., 2005).

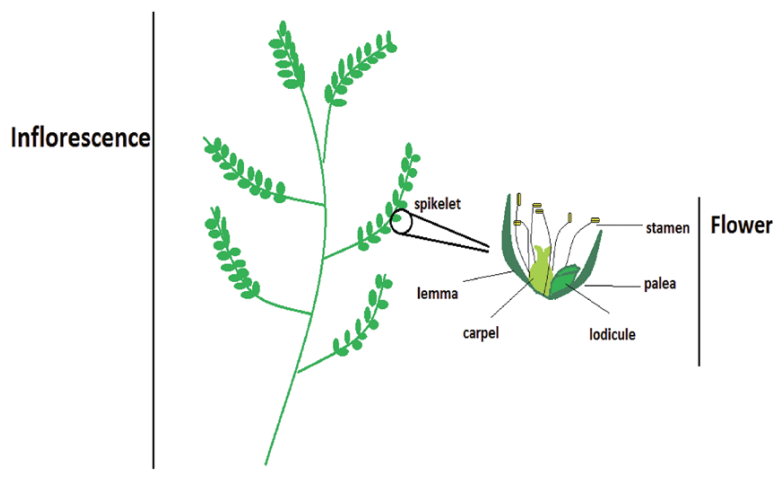

Figure 1. Flower structure in grasses based on the example of rice.

\section{GENETIC REGULATION OF FLOWER DEVELOPMENT- THE ABCDE MODEL}

The original ABC flower development model was proposed in 1991 based on the analysis of the phenotypes of floral homeotic mutants with the significant disturbances in floral organ development, whorls in particular. The study was carried out in model eudicots, such as Arabidopsis thaliana and Antirrbinum majus (Coen \& Meyerowitz, 1991). Angiosperm flowers usually have four whorls. According to the original model, in the first whorl only the A genes (APETALA1, AP1; APETALA2, AP2) are expressed in addition to the standard leaf developmental genes, and this results in sepal development. In the second whorl, both the $\mathrm{A}$ and $\mathrm{B}$ genes (APETALA3, AP3; PISTILLATA, PI) are functional, and this results in petal production. In the third whorl, the $\mathrm{B}$ and $\mathrm{C}$ genes (AGAMOUS, $A G$ ) are expressed which promotes stamen production, and in the last whorl only the $\mathrm{C}$ class genes are active and therefore the development of carpels occurs (Coen \& Meyerowitz, 1991). Later, the $\mathrm{D}$ (STK) and E (SEPALLATA1/2/3/4, SEP1/2/3/4, SHATTERPROOF1, SHP1, and SHP2) genes were added to the $\mathrm{ABC}$ model. The $\mathrm{D}$-class genes are responsible for ovule specification. What is more, based on phylo-

e-mail: aleksandra.smoczynska@amu.edu.pl (AS); zofszwey@amu. edu.pl (ZSZ-K)

Abbreviations: REP1, RETARDED PALEA1; DPI, DEPRESSED PALEA1; IDS1, INDETERMINATE SPIKELET1; SPW1, SUPERWOMAN1; DL, DROOPING LEAF; TS4, TASSELSEED4; SPM, spikelet pair meristem; SID1, SISTER OF INDETERMINATE SPIKELET1, SNB, SUPERNUMERARY BRACT; SCL, SCARECROW-LIKE 
genetic studies, the D-class genes originated from the C-class genes as a result of gene duplications that occurred during evolution before divergence of the eudicot and gymnosperms lineages (Kramer et al., 2004). The E-class genes determine the identity of all four whorls of floral organs, since the proteins that are being produced from those genes create functional complexes with the A, B, C and D proteins (Colombo et al., 1995; Pelaz et al., 2000; Favaro et al., 2003; Pinyopich et al., 2003).

Although this model has not been yet fully characterized in grasses, several studies have been conducted. As in eudicots, presence of the A, B, C, D, E-class genes has been confirmed.

In the case of $\mathrm{A}$ genes, there are three AP1-like genes present in the rice genome (OsMADS14/RAP1B, OsMADS15/RAP1A and OsMADS18) (Litt et al., 2003). Phenotype of the osmads15/rap1a mutant shows that this gene is an important factor in palea development in rice (Wang et al., 2010). However, the triple mutant of OsMADS14, 15 and OsMADS18 forms normal palea and lemma structures (Kabayashi et al., 2012). It appears that development of palea, at least in rice, is also regulated by the REP1 (RETARDED PALEA1) and DPI (DEPRESSED PALEA1) genes. Significantly smaller paleas with delayed differentiation were observed in the case of rep 1 mutant and severe deformation in the central region of paleas in the case of $d p i$ mutant (Yuan et al., 2009, Jin et al., 2011). In the paper from 2012, SUPERNUMERARY BRACT (SNB) and Os INDETERMINATE SPIKELET1 (OSIDS1) - two AP2-like genes were identified in rice to be necessary for lodicule development (Nair et al., 2010; Lee et al., 2012,).

In grasses, the B class of floral identity genes is functionally most similar to those present in eudicots, and therefore it is the best characterized group. In rice, there are two genes that are eudicot PI orthologues- MADS2 and $M A D S 4$. Suppression of OsMADS2 results in developmental differences in lodicules does not cause changes in stamen but (Prasad et al., 2003). No alteration in lodicule or stamen is induced in a OsMADS4 gene mutant, but double mutant of OsMADS2 and OsMADS4 displays occurrence of palea-like organs instead of lodicule, and carpel-like structures in place of stamens (Yao et al., 2008). Mutants of MADS16/ SUPERWOMAN1 (SPW1) in rice, and SI1 in maize (homologs of AP3), result in transformation of the second whorl lodicules into paleas and lemmas, and conversion of stamens into carpels (Kang et al., 1998). This phenotype is essentially identical to the eudicots' B-class genes' mutant (Ambrose et al., 2000, Nagasawa et al., 2003 Whipple et al., 2004).

In grasses, the $\mathrm{C}$ class genes (similar to $A G$ genes in eudicots) are responsible for development of both types of reproductive organs. Based on the phylogenetic approach, there are four $A G$-like genes present in the rice genome and six in maize (OsMADS58, OsMADS21, OsMADS13, OsMADS3 and ZmZAG1, ZmZMM2/ ZmZMM23, ZmZAG2/ZmZMM1, ZmZMM25) (Ciaffi et al., 2011). Loss of OsMADS3 function results in conversion of stamen into lodicule, with no effect on the carpels' development, although OsMADS58 knock-down shows disturbance in the carpel structures. That suggests that there is no single gene responsible for stamen and carpel specification, in contrast to the so far studied eudicots (Yamagushi et al., 2006). Phenotype similar to the mads 58 mutant was shown in the case of maize zmzag1 mutant (Mena et al., 1996). Moreover, in rice the DL (DROOPING LEAF) gene has been identified as a C-class gene taking part in the carpel development. Mutation in this gene results in conversion of carpels into stamens (Yamagushi et al., 2004). OsMADS13 and $O s M A D S 21$, and their maize homologs (ZmZAG2/ $Z m Z M M 1$ and $Z m Z M M 25$ ), have been categorized as the $\mathrm{D}$-class genes originated from $\mathrm{C}$-class genes in the course of major gene duplications. OsMADS13 is predominantly expressed in the ovule where its expression overlaps with OsMADS21 (expression pattern is similar to STK gene in Arabidopsis) (Kramer et al., 2004). Knock-out mutant of OsMADS13 displayed a complete female sterility (Dreni et al. 2007).

The $\mathrm{E}$ class genes also have been characterized in grasses. Ten genes belonging to that category have been identified in maize and seven in rice, and these are homologs of SEP and AGL6 genes in eudicots. Their expression pattern suggests that they all play an important role in the flower meristem determinacy (Theissen et al., 2000). A mutant of one of the SEP-like genes (Os$M A D S 1)$ in rice, produces flowers with palea and lemma-like lodicule and abbreviated number of stamen and carpels; a similar phenotype is produced in a mads6 mutant (Jeon et al., 2000). The complexity of flower development model in grasses can be a result of its much more complexed genome than is present in Arabidopsis (Fig. 2).

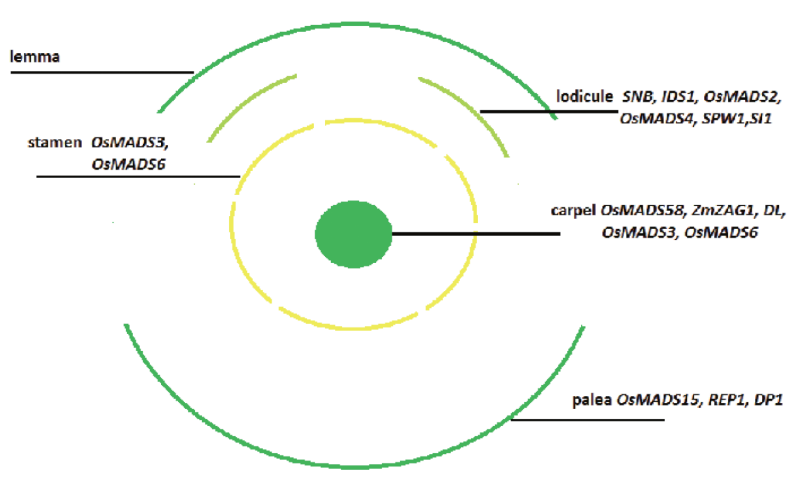

Figure 2. Flower diagram based on the example of rice, with genes corresponding to the development of the flower organs. Due to difficulties with the placement of the classification of individual genes into classes from the ABCDE model in the figure, we provide this classification here: Class A genes - SNB, IDS1, OsMADS15, REP1, DP1, Class B genes - OsMADS2, OsMADS4, SPW1, SI1, Class C genes - OsMADS58, ZmZAG1, DL, OsMADS3, Class E genes - OsMADS3, OsMADS6.

\section{MIRNA-MEDIATED REGULATION OF THE FLOWER ORGAN DEVELOPMENT IN GRASSES}

MiRNAs are small ribonucleic acid molecules (typically $21 \mathrm{nt}$ in length) which, when incorporated into multi-protein complex RISC (RNA-induced silencing complex), are part of an important regulatory mechanism of gene expression at the transcriptional and posttranscriptional level (Lee et al., 1993; Voinnet et al., 2009; Bartel, 2009; Bielewicz et al., 2012; Bielewicz et al., 2013; Szweykowska-Kulińska et al., 2013). MiRNAs are also a vital element of plant adaptation to changing environmental conditions which was studied in plants responding to the stresses of heat, salinity or excess and deficiency of $\mathrm{Cu}$ and $\mathrm{Cd}$ (Kruszka et al., 2012; Kruszka et al., 2014; Barciszewska-Pacak et al., 2015). Moreover, the impact of miRNA-mediated regulation on plant growth and development was shown in the case of miRNA393 and an auxin-signaling pathway in Arabidopsis thaliana (Windels et al., 2014). Studies conducted so far suggest that the miRNAs' activity is essential in all phases of plant life. 


\section{miRNA172}

MiRNA172 is conserved among higher plants and it acts at the transcriptional and translational level as a regulator of the plant-specific transcription factor and floral organ identity gene APETALA2 (AP2), as well as AP2-like genes, including TARGET OF EAT1 (TOE1), TOE2, TOE3, SCHLAFMUTZE (SMZ), and $S C H N A R C H Z A P F E N$ (SNZ) in Arabidopsis (Park et al., 2002; Aukerman et al., 2003; Schmid et al., 2003; Chen, 2004). Also, overexpression of miR172 causes conversion of sepals and petals into carpels and reduction in the stamen number (Chen, 2004).

There have been several studies establishing the role of miRNA172 in maize, rice and barley (Chuck, 2007; Zhu et al., 2009; Nair et al., 2010).

In barley, suppression of AP2-like mRNA cleavage mediated by miRNA172 results in occurrence of cleistogamus flowering, which means that palea and lemma are closed together during the period of pollen release (Lord, 1981; Nair et al., 2010). That situation is caused by the atrophy of lodicule. Under natural conditions, the lodicule swells upon flower opening, pulling the palea and lemma away and ensuring access to carpel and stamens (Bommert et al., 2005). Cleistogamy in barley is under control of a single locus-cleistogamy $1(\operatorname{cly} 1)$ (Turuspekov 2004). Cly1 encodes a transcription factor belonging to the euAP2 family with two AP2 domains. miRNA172 targeted sequence is embedded in the 10th exon of this gene which is common for a number of AP2 genes (Aukerman, 2003; Chen, 2004).

The role of miRNA172 was also established in maize.

Maize is a monoecious plant having tassels and ears which contain male and female reproductive organs. Flowers start as bisexual but then undergo stamen arrest in the ear, and the abortion of pistils in the tassel (Cheng, 1983). The tasselseed4 (ts4) mutant in maize displayed feminization of the tassel caused by a lack of pistil abortion (Phipps, 1928) (Fig. 3).

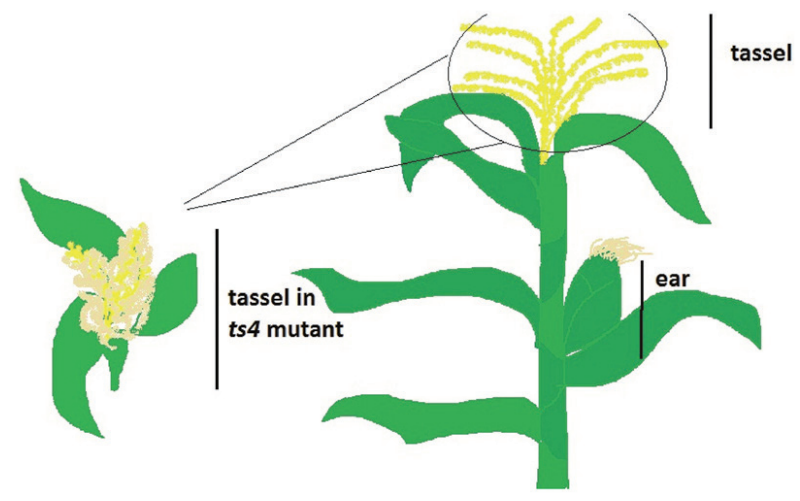

Figure 3. Schematic representation of the wild - type tassel in maize (right) and feminized tassel in the ts4 mutant (left).

TS4 also plays a part in SPM and spikelet meristem determinacy. Inflorescence is initiated from the meristem that under normal conditions produces a regular structure of spikelet pair meristems (SPMs). In case of the $t s 4$ mutants, the SPMs produced spikelet meristems that display a very irregular pattern. Moreover, it has been established that the TS4 gene encodes the miRNA172e. Transgenic plants with an insertion within the pri-microRNA transcription unit were produced and the phenotype of these plants was similar to the ts $4 \mathrm{mu}-$ tant (Chuck et al., 2007). MiRNA172e is present in tassel and ears in wild-type plants but undetectable in these structures in the ts 4 mutants (Chuck et al., 2007). The zma-miR172e target is the AP2-like gene INDETERMINATE SPIKELET1 (IDS1) that is required for spikelet meristem determinacy. An ids1/ ts 4 double mutant had almost completely blocked the defects observed in the ts4 tassels, supporting the hypothesis that IDS1 mRNA is a target for miRNA172 (Chuck et al., 2007).

A year later, it has been established that also another gene is regulated by miR172e in maize - SISTER OF INDETERMINATE SPIKELET1 (SID1). No mutant phenotype has been observed in single sid1 mutants, but ids $1 /$ sid1 double mutants produced fewer tassel branches and generated defects in flower development, proving that miRNA172e targets both AP2-like gene mRNAs: IDS1 and SID1 (Chuck et al., 2008).

The role of miRNA172 has been also studied in the case of rice.

The rice miR172 family contains four members (miR172 a-d) which are predicted to target five AP2-like genes: Os03g60430, Os04g55560, Os05g03040, Os06g43220 and $\mathrm{OsO7g}_{13170}$ (Zhu et al., 2009, Lee 2007). One of them - Os07g13170 (SNB - SUPERNUMERARY $B R A C T$ ) has been shown to be required for determination of floral organ identity. The snb mutant displays defects in the floral organ development (Lee, 2007). SNB, Os03g60430, Os05g03040 and Os06g43220 are the putative rice orthologues of maize SID1, IDS1, ZmRap2.7 and GL15, respectively (Chuck et al., 2008). Cleavage of the Os04g55560 mRNA by the miR172 was detected in a shoot and grain, as well as in the booting panicles, while cleavage of the Os06g43220 mRNA was only detected in the mixed sample of shoot and grain with a low frequency, and cleavage of the $S N B$ mRNA was only detected in the booting panicles. Overexpression of the MIR172b in rice causes abnormalities in the flower organ development, including multiple layers of lem$\mathrm{ma}$ and palea, twisted lemma and palea, degeneration of either lemma or palea or leaf-like structures replacing them, while in some cases no obvious floral organs were produced (Zhu et al., 2009).

These phenotypes are in agreement with results acquired by the snb mutants, suggesting that $S N B$ and at least one of the other four targets of miR172 were repressed in plants over-expressing miR172b (Zhu et al., 2009).

\section{miRNA159}

Overexpression of AtmiR159 in Arabidopsis resulted in various phenotypic changes including anther defects or male sterility, therefore it is believed that miR159 and its target genes are involved in important developmental processes (Achard et al., 2004). In Arabidopsis, miRNA159 targets GAMYB-like genes (Palatnik et al., 2003, Achard et al., 2004, Millar et al., 2005, Schwab et al., 2005). AtMYB33 and AtMYB65 belong to the GAMYB-like genes (Stracke et al., 2001) and their double mutant displays male sterility and anther defects (Millar et al., 2005).

MiRNA159 target sequence was also reported in rice OsGAMYB transcription factors (OsGAMYBL1 and OsGAMYBL2). Also, OsGAMYBL1 was specifically expressed in flowers and co-expressed with miR159 (Hiroyuki et al., 2006). Overexpression of miR159 in rice caused development of deformed flowers. In a mild phenotype, the flowers were sterile and developed either shrunken and whitened anthers, or slightly reduced 
lemma and palea. In a severe phenotype, the palea and lemma production was distorted and flowers were much smaller than in the wild-type plants. They also did not develop stamen and pistil primordia (Tsuji et al., 2006). The knockout mutant of OsGAMYBL1, gamyb-1, showed similar defects (Kaneko et al., 2004).

\section{miRNA171}

MiR171 is a member of a well-known family of miRNAs that target the transcription factor SCL (SCARECROW-LIKE), belonging to a protein family named GRAS (Bolle, 2004). Those proteins are important in the flowering control and apical meristem development (Lee et al. 2008). In Arabidopsis, three MIR171 genes can be distinguished ( $a, b$ and $c$ ) and miRNAs produced from them target the SCL6 genes (Schulze et al., 2010; Engstrom et al., 2011). Phenotypes of transgenic plants over-expressing miR171c and the sclo mutant display similarities, including altered flower structure, which suggests that miR171 can reduce the level of SCL6 and takes part in these developmental processes (Wang et al., 2010).

In barley, two mature miR171 sequences (hvumiR171a/b) have been identified (Schreiber et al., 2011). There are also nine rice, fourteen maize and four Brachypodium miR171 family members. MiRNA171 is mostly expressed in the reproductive tissues. miR171 directs specific cleavage of the SCL target mRNAs in rice and barley. Moreover, overexpression of miR171 in rice resulted in a phenotype with altered shoot structure, delayed flowering and spikes' sterility (Curaba et al., 2013).

\section{miRNA396}

MiRNA396 is a well-conserved miRNA. Recently, involvement of miRNA396 in the control of carpel number and pistil development in Arabidopsis via targeting nine GROWTH REGULATORY FACTORS (GRF) has been established (Liang et al., 2014). There are also nine GRF genes targeted by miRNA396 in rice, with GRF6 being the predominant one. Transgenic rice plants overexpressing miR396 displayed malformed flower structures and this effect was correlated with a significant down-regulation of GRF6 and other members of this family. What's more, this phenotype could be rescued by the expression of GRFG carrying changes in the miRNA396 targeted sequence (Liu et al., 2014).

\section{SUMMARY}

The ABC model of floral organ specification, which was established based on the study of model eudicots, in most part can be applied in the case of grasses as well. Genes in the A class are responsible for the palea development (homologs of eudicot sepals) which was for example shown in the case of the MADS15 gene in rice (Wang et al., 2010). The class B genes are required for the specification of organs in the second whorl which was confirmed in mutants of MADS16/ SUPERWOM$A N 1$ (SPW1) in rice and SI1 in maize (homologs of AP3) (Kang et al., 1998; Whipple et al., 2004; Ambrose et al., 2000; Nagasawa et al., 2003). Also, the role of the C-class genes in grasses is similar to those in eudicots. Their involvement in development of reproductive organs was depicted in the loss of function mutant of $M A D S 3$, and knock-down mutants in the MADS58 genes in rice (Yamagushi et al., 2006).
MiRNAs can regulate flower organ development and flowering time in grasses. In barley, miRNA172 targets a sequence embedded in the AP2-like gene responsible for occurrence of the flower cleistogamy (Nair et al., 2010). In maize, feminization of the tassel caused by a lack of pistil abortion occurs due to the lack of miRNA172 expression (Chuck, 2007). In rice, miRNA 172 targets the floral organ identity gene (SNB SUPERNUMERARY BRACT), and it's overexpression also results in many problems in the organ development, such as: twisted lemma and palea, degeneration of either lemma or palea, replacement by leaf-like structures or in some cases lack of floral organ production (Phipps et al., 1928; Chuck et al., 2007; Zhu et al., 2009). Also, another miRNA, miR159 regulates the flower organ development in grasses. miR159 targets the GAMYB-like gene and overexpression of miR159 in rice causes development of malformed flowers within the leaf sheaths, shrunken and whitened anthers, reduced lemma and male sterility (Hiroyuki et al., 2006). Another miRNA that affects flowers in grasses is miRNA171. miRNA171 is found to target the SCL gene involved in control of flowering. There are several members of this family found in rice, Brachypodium and maize. Overexpression of miR171 in rice resulted in a pleiotropic phenotype with delayed flowering and partially sterile spikes (Curaba et al., 2013). Also, miRNA396 regulates the flower development in grasses by targeting the GRF6 gene which was documented in the case of rice (Liu et al., 2014).

A model of floral development in grasses and its genetic regulation is not yet fully characterized. Further studies on both, the model eudicots and grasses, are required to elucidate this mechanism.

\section{Acknowledgements}

KNOW RNA Research Centre in Poznan, 01/ KNOW2/2014.

\section{REFERENCES}

Achard P, Herr A, Baulcombe DC, Harberd NP (2004) Modulation of floral development by a gibberellin-regulated microRNA. Development 131: 3357-3365. http://dx.doi.org/10.1242/dev.01206

Ambrose BA, Lerner DR, Ciceri P, Padilla CM, Yanofsky MF, Schmidt RJ (2000) Molecular and genetic analyses of the silky1 gene reveal conservation in floral organ specification between eudicots and monocots. Mol Cell 5: 569-579. http://dx.doi.org/10.1016/S10972765(00)80450-5

Aukerman MJ, Sakai H (2003) Regulation of flowering time and floral organ identity by a microRNA and its APETALA2-like target genes. The Plant Cell 15: 2730-2741. http://dx.doi.org/10.1105/tpc.016238

Barciszewska-Pacak M, Milanowska K, Knop K, Bielewicz D, Nuc P, Plewka P, Pacak AM, Franck Vazquez F, Karlowski W, Jarmolowski A, Szweykowska-Kulinska Z (2015) Arabidopsis microRNA expression regulation in a wide range of abiotic stress responses. Front Plant Sci 6: 410. http://dx.doi.org/10.3389\%2Ffpls.2015.00410

Bartel DP (2009) MicroRNAs: target recognition and regulatory functions. Cell. 136: 215-233. http://dx.doi.org/doi: 10.1016/j. cell.2009.01.002.

Bielewicz D, Dolata J, Zielezinski A, Alaba S, Szarzynska B, Szczesniak MW. Jarmolowski A, Szweykowska-Kulinska Z, Karlowski W (2012) mirEX: a platform for comparative exploration of plant pri-miRNA expression data. Nucleic Acids Res 40: 191-197. http:// dx.doi.org/10.1093/nar/gkr878

Bielewicz D, Kalak M, Kalyna M, Windels D, Barta A, Vazquez F, Szweykowska-Kulinska Z, Jarmolowski A (2013). Introns of plant primiRNAs enhance miRNA biogenesis. EMBO Reports 14: 622628. doi: 10.1038/embor.2013.62

Bolle C (2004) The role of GRAS proteins in plant signal transduction and development. Planta 218: 683-692. http://dx.doi.org/10.1007/ s00425-004-1203-z

Bommert P, Satoh-Nagasawa N, Jackson D, Hirano H-Y (2005) Genetics and evolution of inflorescence and flower development in grasses. Plant Cell Physiol 46: 69-78. http://dx.doi.org/10.1093/pcp/ pci504 
Chen X (2004) A microRNA as a translational repressor of APETALA2 in Arabidopsis flower development. Science 303: 2022-2025. http://dx.doi.org/10.1126/science.1088060

Cheng PC, Greyson RI, Walden DB (1983) Organ initiation and the development of unisexual flowers in the tassel and ear of Zea mays. Am J Bot 70: 450-462. http://dx.doi.org/10.2307/2443252

Chuck G, Meeley R, Hake S (2008) Floral meristem initiation and meristem cell fate are regulated by the maize AP2 genes ids1 and sid1. Development 135: 3013-3019. http://dx.doi.org/10.1242/dev.024273

Chuck G, Meeley R, Irish E, Sakai H, Hake S (2007) The maize tasselseed4 microRNA controls sex determination and meristem cell fate by targeting Tasselseed6/indeterminate spikelet1. Nature 39: 1517-1521. http://dx.doi.org/doi:10.1038/ng.2007.20

Ciaffi C, Paolacci AR (2011) Molecular aspects of flower development in grasses. Sex Plant Reprod 24: 247-282. http://dx.doi.org/ doi10.1007/s00497-011-0175-y

Clifford H T (1987). Spikelet and floral morphology. In Grass Systematics and Evolution. TR Soderstrom, KW Hilu, CS Campbell, ME Barkworth eds, pp 21-30. Washington Smithsonian Institute Press

Coen ES, Meyerowitz EM (1991) The war of the whorls: genetic interactions controlling flower development. Nature 353: 31-37 http:// dx.doi.org/10.1038/353031a0

Colombo L, Franken J, Koetje E, van Went J, Dons HJ, Angenent GC, van Tunen AJ (1995) The petunia MADS box gene FBP11 determines ovule identity. Plant Cell 7: 1859-1868. http://dx.doi.org/ 10.1105/tpc.7.11.1859

Curaba J, Spriggs A, Taylor J, Li Z, Helliwell C (2012) MiRNA regulation in the early development of barley seed. BMC Plant Biol 12: 120. http://dx.doi.org/10.1186/1471-2229-12-120.

Dreni L, Jacchia S, Fornara F, Fornari M, Ouwerkerk PB, An G, Colombo L, Kater MM (2007) The D-lineage MADS-box gene OsMADS13 controls ovule identity in rice. Plant J 52: 690-699. http://dx.doi.org/10.1111/j.1365-313X.2007.03272.x

Engstrom EM (2011) Phylogenetic analysis of GRAS proteins from moss, lycophyte and vascular plant lineages reveals that GRAS genes arose and underwent substantial diversification in the ancestral lineage common to bryophytes and vascular plants. Plant Signal Behav 6: 850-854. http://dx.doi.org/10.4161/psb.6.6.15203

Favaro R, Pinyopich A, Battaglia R, Kooiker M, Borghi L, Ditta G, Yanofsky MF, Kater MM, Colombo L (2003) MADS-box protein complexes control carpel and ovule development in Arabidopsis. Plant Cell 15: 2603-2611 http://dx.doi.org/10.1105/tpc.015123

Jeon JS, Jang S, Lee S, Nam J, Kim C, Lee SH, Chung YY, Kim SR, Lee YH, Cho YG, An G (2000) leafy hull sterile1 is a homeotic mutation in a rice MADS box gene affecting rice flower development. Plant Cell 12: 871-884. http://dx.doi.org/10.1105/tpc.12.6.871

Jin Y, Luo Q, Tong $\mathrm{H}$, Wang A, Cheng Z, Tang J, Li D, Zhao X, Li X, Wan J, Jiao Y, Chu C, Zhu L (2011) An AT-hook gene is required for palea formation and $\mathrm{fl}$ oral organ number control in rice. Dev Biol 359: 277-288. http://dx.doi.org/10.1016/j. ydbio.2011.08.023

Kaneko M,Inukai Y, Ueguchi-Tanaka M, Itoh H, Izawa T, Kobayashi Y, Hattori T, Mivao A, Hirochika H, Ashikari M, Matsuoka M (2004) Loss-of-function mutations of the rice GAMYB gene impair $\alpha$-amylase expression in aleurone and flower development. Plant Cell 16: 33-44. http://dx.doi.org/10.1105/tpc.017327

Kang HG, Jeon JS, Lee S, An G (1998) Identification of class B and class C floral organ identity genes from rice plants. Plant Mol Biol 38: 1021-1029. http://dx.doi.org/10.1023/A:1006051911291

Kobayashi K, Yasuno N, Sato Y, Yoda M, Yamazaki R, Kimizu M, Yoshida H, Nagamura Y, Kyozuka J (2012) Inflorescence meristem identity in rice is specified by overlapping functions of three AP1/ FUL-Like MADS box genes and PAP2, a SEPALLATA MADS box gene. Plant Cell 24: 1848-1859. http://dx.doi.org/10.1105/ tpc.112.097105

Kramer EM, Jaramillo MA, Di Stilio VS (2004) Patterns of gene duplication and functional evolution during the diversification of the AGAMOUS subfamily of MADS box genes in angiosperms. Genetics 166: 1011-1023. http://dx.doi.org/10.1534/166.2.1011

Kruszka K, Pacak A, Swida-Barteczka A, Nuc P, Alaba S, Wroblewska Z, Karlowski W, Jarmolowski A, Szweykowska-Kulinska Z (2014) Transcriptionally and post-transcriptionally regulated microRNAs in heat stress response in barley. J Exp Bot 65: 6123-6135. http:// dx.doi.org/10.1093/jxb/eru353

Kruszka K, Pieczynski M, Windels D, Bielewicz D, Jarmolowski A, Szweykowska-Kulinska Z, Vazquez F (2012) Role of microRNAs and other sRNAs of plants in their changing environments. J Plant Physiol 169: 1664-1672. http://dx.doi.org/10.1016/j. jplph.2012.03.009

Lee D, An G (2012) Two AP2 family genes, SUPERNUMERARY BRACT (SNB) and OSINDETERMINATE SPIKELET 1 (OsIDS1), synergistically control inflorescence architecture and floral meristem establishment in rice. Plant J 69: 445-461. http://dx. doi.org/10.1111/j.1365-313X.2011.04804.x

Lee DY, Lee J, Moon S, Park SY, An G (2007) The rice heterochronic gene SUPERNUMERARY BRACT regulates the transition from spikelet meristem to floral meristem. Plant J 49: 64-78. http://dx. doi.org/10.1111/j.1365-313X.2006.02941.x.

Lee MH, Kim B, Song SK, Heo JO, Yu NI, Lee SA, Kim M, Kim DG, Sohn SO, Lim CE, Chang KS, Lee MM, Lim J (2008) Largescale analysis of the GRAS gene family in Arabidopsis thaliana. Plant Mol Biol 67: 659-670. http://dx.doi.org/10.1007/s11103-008-9345-1

Lee RC, Feinbaum RL, Ambros V (1993) The C. elegans heterochronic gene lin-4 encodes small RNAs with antisense complementarity to lin-14. Cell 75: 843-854. http://dx.doi.org/10.1016/00928674(93)90529-Y.

Liang G, He H, Li Y, Wang F, Yu D (2014) Molecular mechanism of microRNA396 mediating Pistil development in Arabidopsis1. Plant Physiol 164: 249-258. http://dx.doi.org/10.1104/pp.113.225144

Litt A, Irish VF (2003) Duplication and diversification in the APETALA1/FRUITFULL floral homeotic gene lineage: Implications for the evolution of floral development. Genetics 165: 821-833

Liu H, Guo S, Xu Y, Li C, Zhang Z, Zhang D, Xu S, Zhang C, Chong K (2014) OsmiR396d-regulated OsGRFs function in floral organogenesis in rice through binding to their targets OsJMJ706 and OsCR41. Plant Physiol 165: 160-174. http://dx.doi.org/10.1104/ pp.114.235564

Lord EM (1981) Cleistogamy: A tool for the study of floral morphogenesis, function and evolution. Bot Rev 47: 421-449

Mena M, Ambrose BA, Meeley RB, BriggsSP, Yanofsky MF, Schmitt RJ (1996) Diversification of C-function activity in maize flower development. Science 274: 1537-1540. http://dx.doi.org/10.1016/ S1360-1385(97) 82558-7

Millar AA, Gubler F (2005) The Arabidopsis GAMYB-like genes, MYB33 and MYB65, are microRNA-regulated genes that redundantly facilitate anther development. Plant Cell 17: 705-721. http:// dx.doi.org/10.1105\%2Ftpc.104.027920

Nagasawa N, Miyoshi M, Sano Y, Satoh H, Hirano H, Sakai H, Nagato Y (2003) SUPERWOMAN1 and DROOPING LEAF genes control floral organ identity in rice. Development 130: 705-718. http://dx.doi.org/doi:10.1242/dev.00294

Nair S, Wang N, Turuspekov Y, Pourkheirandish M, Sinsuwongwat S, Chen G, Sameri M, Tagiri A, Honda I, Watanabe Y, Kanamori H, Wicker T, Stein N, Nagamura Y, Matsumoto T, Komatsuda T (2010) Cleistogamous flowering in barley arises from the suppression of microRNA-guided HvAP2 mRNA cleavage. PNAS 107: 490-495. http://dx.doi.org/doi:10.1073/pnas.0909097107

Palatnik JF, Allen E, Wu XL, Schommer C, Schwab R, Carrington JC, Weigel D (2003) Control of leaf morphogenesis by microRNAs. Nature 425:257-263 http://dx.doi.org/10.1038/nature01958

Park W, Li J, Song R, Messing J, Chen X (2002) CARPEL FACTORY, a Dicer homolog, and HEN1, a novel protein, act in microRNA metabolism in Arabidopsis thaliana. Curr Biol 12: 1484-1495. http:// dx.doi.org/10.1016/S0960-9822(02)01017-5

Pelaz S, Ditta GS, Baumann E, Wisman E, Yanofsky MF (2000) B and C floral organ identity functions require SEPALLATA MADS-box genes. Nature 405: 200-203 http://dx.doi.org/doi:10.1038/35012103 Phipps IF (1928) Heritable characters in maize. XXXI. Tassel-seed4. J Hered 19: 399-404

Pinyopich A, Ditta GS, Savidge B, Liljegren SJ, Baumann E, Wisman E, Yanofsky MF (2003) Assessing the redundancy of MADS-box genes during carpel and ovule development. Nature 424: 85-88 http://dx.doi.org/doi:10.1038/nature01741

Prasad K, Vijayraghavan U (2003) Double-stranded RNA interference of a rice PI/GLO paralog, OsMADS2, uncovers its second-whorl-specific function in floral organ patterning. Genetics 165: 2301-2305

Schmid M, Uhlenhaut NH, Godard F, Demar M, Bressan R, Weigel D, Lohmann JU (2003) Dissection of floral induction pathways using global expression analysis. Development 130: 6001-6012. http:// dx.doi.org/doi:10.1242/dev.00842

Schreiber AW, Shi BJ, Huang CY, Langridge P, Baumann U (2011) Discovery of barley miRNAs through deep sequencing of short reads. BMC Genomics 12: 129. http://dx.doi.org/10.1186/1471-216412-129

Schulze S, Schäfer BN, Parizotto EA, Voinnet O, Theres K (2010) LOST MERISTEMS genes regulate cell differentiation of central zone descendants in Arabidopsis shoot meristems. Plant J 64: 668678. http://dx.doi.org/10.1111/j.1365-313X.2010.04359.x

Schwab R, Palatnik JF, Riester M, Schommer C, Schmid M, Weigel D (2005) Specific effects of microRNAs on the plant transcriptome. Dev Cell 8: 517-527. http://dx.doi.org/10.1016/j.devcel.2005.01.018

Stracke R, Werber M, Weisshaar B (2001) The R2R3-MYB gene family in Arabidopsis thaliana. Curr Opin Plant Biol 4: 447-456. http://dx.doi. org/10.1016/S1369-5266(00)00199-0

Szweykowska-Kulinska Z, Jarmolowski A, Vazquez F (2013). The crosstalk between plant microRNA biogenesis factors and the spliceosome. Plant Signal Behav 8: e26955. http://dx.doi.org/10.4161/ psb. 26955

Theissen G, Becker A, Di Rosa A, Kanno A, Kim JT, Münster T, Winter K-U, Saedler H (2000) A short history of MADS-box genes in plants. Plant Mol Biol 42: 115-149 
Tsuji H, Aya K, Ueguchi-Tanaka M, Shimada Y, Nakazono M, Watanabe R, Nishizawa NK, Gomi K, Shimada A, Kitano H, Ashikari M, Matsuoka M (2006) GAMYB controls different sets of genes and is differentially regulated by microRNA in aleurone cells and anthers. Plant J 47: 427-444. http://dx.doi.org/10.1111/j.1365313X.2006.02795.x

Turuspekov Y, Mano Y, Honda I, Kawada N, Watanabe Y, Komatsuda T (2004) Identification and mapping of cleistogamy genes in barley. Theor Appl Genet 109: 480-487. http://dx.doi.org/10.1007/ s00122-004-1673-1

Voinnet O (2009) Origin, biogenesis, and activity of plant microRNAs. Cell 136: 669-87. http://dx.doi.org/10.1016/j.cell.2009.01.046.

Wang K, Tang D, Hong L, Xu W, Huang J, Li M, Gu M, Xue Y, Cheng Z (2010) DEP and AFO regulate reproductive habit in rice. PLoS Genet 6: e1000818 http://dx.doi.org/doi:10.1371/journal. pgen.1000818

Wang L, Mai YX, Zhang YC, Luo Q, Yang HQ (2010) microRNA171c-targeted SCL6-II, SCL6-III, and SCL6-IV genes regulate shoot branching in Arabidopsis. Mol Plant 3: 794-806. http://dx. doi.org/10.1093/mp/ssq042

Whipple CJ, Ciceri P, Padilla CM, Ambrose BA, Bandong SL, Schmidt RJ (2004) Conservation of B-class floral homeotic gene function between maize and Arabidopsis. Development 131: 6083-6091. http:// dx.doi.org/10.1242/dev.01523
Windels D, Bielewicz D, Ebneter M, Jarmolowski A, Szweykowska-Kulinska Z, Vazquez F (2014) miR393 is required for production of proper auxin signalling outputs. PLoS One 9: e95972. http://dx. doi.org/10.1371/journal.pone.0095972

Yamaguchi T, Lee DY, Miyao A, Hirochika H, An G, Hirano HY (2006) Functional diversification of the two C-class genes OsMADS3 and OsMADS58 in Oryza sativa. Plant Cell 18: 15-28. http://dx.doi.org/10.1105/tpc.105.037200

Yamaguchi T, Nagasawa N, Kawasaki S, Matsuoka M, Nagato Y, Hirano HY (2004) The YABBY gene DROOPING LEAF regulates carpel specification and midrib development in Oryza sativa. Plant Cell 16: 500-509. http://dx.doi.org/10.1105\%2Ftpc.018044

Yao SG, Ohmori S, Kimizu M, Yoshida H (2008) Unequal genetic redundancy of rice PISTILLATA orthologs, OsMADS2 and OsMADS4, in lodicule and stamen development. Plant Cell Physiol 49: 853-857. http://dx.doi.org/10.1093/pcp/pcn050

Yuan Z, Gao S, Xue D-W, Luo D, Li L-T, Ding S-Y, Yao X, Wilson ZA, Qian Q, Zhang D-B (2009) RETARDED PALEA1 controls palea development and floral zygomorphy in rice. Plant Physiol 149: 235-244. http://dx.doi.org/10.1104\%2Fpp.108.128231

Zhu Q-H, Upadhyaya NM, Gubler F, Helliwell CA (2009) Over-expression of miR172 causes loss of spikelet determinacy and floral organ abnormalities in rice (Oryza sativa). BMC Plant Biology 9: 149 http://dx.doi.org/10.1186/1471-2229-9-149 